\title{
Protective Effects of Spirulina against Cyclophosphamide Induced Bone Marrow Toxicity in Mice
}

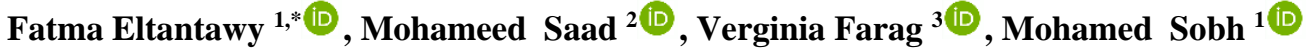 \\ 1 Urology and Nephrology Center, Faculty of medicine, Mansoura University, Mansoura 35511, Egypt; \\ fatma_201014@yahoo.com (F.E.); sob10@yahoo.com (M.A.S.); \\ 2 Department of Pharmacology, Faculty of Medicine, Mansoura University, Mansoura 35511, Egypt; \\ ahady2007@yahoo.com (M.A.S.); \\ 3 Department of Clinical Pathology, Faculty of Veterinary Medicine, Mansoura University, Mansoura, Egypt; \\ faragverginia@gmail.com (V.F.); \\ * Correspondence: fatma_201014@yahoo.com;
}

Received: 12.03.2021; Revised: 15.04.2021; Accepted: 18.04.2021; Published: 26.04.2021

\begin{abstract}
Spirulina Platenesis (Sp) is rich in important compounds with antioxidant effects. This study investigates the treatment and prophylactic effect of Spirulina Platenesis (Sp) against Cyclophosphamide (CP) induced bone marrow toxicity. Fifty female BALB/C mice were randomly classified into 5 equal groups: (1) Normal controls; (2) CP group: injected with $40 \mathrm{mg} / \mathrm{kg}$ for 10 days; (3) Sp group: supplied by Sp (1000 mg/kg) for 10 days; (4) Treatment group: CP + Sp; (5) Prophylactic group: $\mathrm{Sp}+\mathrm{CP}$. After 10 days, At the end of the study period, all rats were killed, blood was withdrawn, and bone marrow $(\mathrm{BM})$ was subjected to investigation. Cyclophosphamide administration caused rapid dimension in CBC parameter, Bone marrow WBC count and Erythropiotein concentration in blood that have been recovered with Sp administration. According to histological analysis of the bone marrow, spirulina impaired the proliferation and hypercellularity of immature myeloid elements in the bone marrow, which CP decreased. Obviously, spirulina may with antioxidative activity reduced the oxidative stress and toxicity induced by cyclophosphamide in mouse bone marrow cells.
\end{abstract}

Keywords: spirulina; toxicity; bone marrow; cyclophosphamide; Erythropiotein.

(C) 2021 by the authors. This article is an open-access article distributed under the terms and conditions of the Creative Commons Attribution (CC BY) license (https://creativecommons.org/licenses/by/4.0/).

\section{Introduction}

Myelosuppression is a severe illness caused by a malfunction in blood cell production that kills patients' bodily functions, lowering their quality of life. Myelosuppression is often caused by chemotherapy drug side effects. Cyclophosphamide (CP) is an alkylating agent that is commonly used as an antineoplastic drug, and it is classified as a "cytotoxic agent". CP is a prevalent anticancer chemotherapeutic agent used to treat patients with malignancy such as breast cancer, lymphomas and leukemias, retinoblastoma, small cell lung cancer, and ovaries cancer, sarcomas, and multiple myeloma. It was named one of the most effective chemotherapy medications on the World Health Organization's List of Essential Medicines [1]. Apoptosis and necrosis, which are both antineoplastic and toxic effects of $\mathrm{CP}$, are related to two active metabolites: acrolein and phosphoramide [2].

Anticancer chemotherapy may cause serious toxic effects, such as nausea, vomiting, and decreased HSCs in the marrow and circulating peripheral blood cells, which have reduced the effectiveness of current chemotherapeutics; chemotherapy-related complications include emaciation, anemia, and immunodeficiency [3]. Anticancer drug exposure has also been shown 
in mice to cause genomic instability that affects multiple generations [4]. Antineoplastic agents are still used in chemotherapy cancer treatment cases because they are toxic to proliferating cells and destroy neoplastic tissue quickly. They will, however, harm normal proliferating cells in the process. As a result, their therapy index drops. As a result, long-term use of these anticancer drugs has become a source of rising interest. CP's mutagenic effects in transgenic mice have been investigated in many experiments. Mutation induction was detected in the bone marrow of Mute mice [5]. Some studies have shown that CP treatment produces carbonium ions, which react with electron-rich sites on nucleic acids and proteins, resulting in the production of reactive oxygen species (ROS) [6]. Although an overall decrease in reduced glutathione (GSH) content has often been reported in various tissues due to CP therapy [7], free radical generation is one of the mechanisms by which $\mathrm{CP}$ and its derivatives exert their toxic effects in different tissues. Tissue antioxidants play an important role in preventing the peroxidative damage caused by $\mathrm{CP}$ therapy. A number of natural products and synthetic compounds have been shown to minimize $\mathrm{CP}$ toxicity primarily through antioxidant action, and these compounds have excellent antioxidant and chemoprotective properties in vivo [8]. The chemoprotective effects of these natural products could be explained by their antioxidant activity [9].

Medicinal plants' bioactive compounds act as a blueprint for preventing or reversing carcinogenesis in its early stages. Furthermore, they are regarded as a low-cost, efficient, and simple-to-implement cancer-control strategy. Herbal drugs are also a valuable part of the healthcare system [10]. Efforts to examine the impacts of natural products for the prevention of many types of cancers have yielded promising findings over the last few decades [11].

Medicinal plants are food supplements that provide not only dietary but also therapeutic benefits [12]. Secondary metabolites such as alkaloids, saponins, terpenoids, flavonoids, tannins, sterols, and phenolic compounds contribute to plants' medicinal value. As a result, the biologically active principles of any plant are crucial [13]. Antimutagens were first discovered nearly four decades ago. Antimutagenic experiments with plant extracts are on the rise, according to several publications [5]. Spirulina Platenesis ( $\mathrm{Sp}$ ) is a microscopic blue-green alga that lives as a single-celled organism and converts sunlight into life energy. It is commonly used around the world [14]. Spirulina powder or tablets are commonly used in the food supplement, pharmaceutical, and health-protection industries $[15,16]$. Previous research has shown that oral Spirulina supplementation can boost the innate immune system, enhance the antioxidant status, and have antihypertensive effects [17].

Iron is necessary for healthy red blood cells and a strong immune system, but most iron supplements are poorly absorbed by humans [18]. In anemic rats, microalgal diets containing more intestinal nanosized iron were discovered to improve non-heme iron absorption. Spirulina outperformed Chlorella, Synechococcus, and $\mathrm{FeSO}_{4}$ to compare high-added microalgal diets to low-added microalgal diets [19].

Erythropoietin (Epo) is a hematopoietic glycoprotein hormone that promotes the production of red blood cells. Epo regulates the production of red blood cells by promoting the survival, proliferation, and differentiation of erythroid progenitors in the bone marrow [20].

The regulation of Epo production is an essential feature of tissue oxygenation control since red cells' primary function is to transport oxygen from the lungs to peripheral tissues. As a result, hypoxia regulates the production of Epo, which is the only hematopoietic growth factor [21]. 
Erythropoietin has tissue-protective effects in other tissues as well, implying a stereotypic mechanism, possibly involving endothelial cells as a key player. In fact, the endothelium was the first non-hematopoietic tissue to be identified as an Epo target [22].

This research was conducted to evaluate Spirulina extract's effects against the toxicity caused by $\mathrm{CP}$ in mouse bone marrow cells because it has been widely used as an additive agent and is known to be safe. The potential mitigating effects of the Spirulina extract against the myelosuppressive effect of $\mathrm{CP}$ and bone marrow suppression were also investigated using a histological examination of the bone marrow.

\section{Materials and Methods}

2.1. Materials.

2.1.1. Cyclophosphamide (CP).

Endoxan was purchased from Baxter Oncology Chemical Co. (Egypt) was dissolved in physiological saline $(0.9 \% \mathrm{NaCl})$ for intraperitoneal (i.p) injection.

\subsection{2. spirulina.}

A fine dark blue-green powder of Spirulina Platensis (Sp) thankfully was provided by doctor Yassin .N.ELayouty Professor of Phycology, Botany Department Faculty of Science, Zagazig University. Spirulina was suspended in sterile distilled water and given orally to the mice.

\subsection{Methods.}

2.2.1. Animals and experimental protocol.

This study included 50 female BALB/ C mice aging 6 weeks and weighing 25-30 grams each. The animals were obtained from the Animal Resources Unit, Medical Experimental Research Center (MERC), Mansoura University. The mice were kept in clean plastic cages and fed on a standard mice pellet diet and water ad labium. They were kept on a 12:12 hr. light and dark cycle during the experimental period. The temperature was controlled at $23 \pm 1{ }^{\circ} \mathrm{C}$ and humidity at $55 \pm 10 \%$. The control mice were kept separated from the test groups in the same temperature and humidity as the test groups mice and fed on the same food.

The mice were randomized into control, and experimental groups were divided into 5 groups.

The control group $(n=10)$ received an intraperitoneal injection with $0.9 \%$ physiological saline once a day for 10 days.

Cyclophosphamide group $(\mathrm{n}=10)$ received Cyclophosphamide intraperitoneal injection with dose $(40 \mathrm{mg} / \mathrm{kg})$ once a day for 10 days.

Spirulina group $(\mathrm{n}=10)$ received Sp orally in a dose of $1000 \mathrm{mg} / \mathrm{kg}$ b.wt /day for 10 days.

Treatment group ( $\mathrm{n}=10$ ) intraperitoneal injection with CP $40 \mathrm{mg} / \mathrm{kg}$ b.wt /day for 10 days and Sp in a dose of $1000 \mathrm{mg} / \mathrm{kg} \mathrm{b}$.wt / day was given orally during the last 5 days.

Prophylactic group $(n=10)$ mice of this group were given Sp orally in a dose of 1000 $\mathrm{mg} / \mathrm{kg}$ b.wt /day for 10 days, and CP was administrated i.p. in a dose of $40 \mathrm{mg} / \mathrm{kg} \mathrm{b.wt} /$ day in the last 5 days. 
In the day of termination, whole blood was withdrawn from each mouse of all groups by cardiac puncture and was divided into 2 parts, $2 \mathrm{ml}$ on EDTA for $\mathrm{CBC}$, and the rest was left in a plain tube for preparation of serum from clotted blood by centrifugation at $2000 \mathrm{rpm}$ for 5 min for EPO determination. Complete blood pictures were done by Sysmex Automatic Hematology Analyzer SF-300 (Sysmex Corporation, KOBE,JAPAN).

\subsubsection{Estimation of erythropoietin.}

Erythropoietin Epo in mice serum was estimated by enzyme-linked immunosorbent assays (ELISA) technique which was manufactured and distributed by USA \& Canada, R\&D Systems, Inc.

All mice were sacrificed using thiopental $(50 \mathrm{mg} / \mathrm{kg}$ (i.p)) at the end of the 10 days. Bone marrow has been isolated from tibias and femur at the time of scarification. The bone marrow was flushed into $50 \mathrm{ml}$ Falcon tube by using a 26-gauge needle connected with the 5 $\mathrm{ml}$ syringe containing phosphate-buffered saline (PBS) at the knee side of both types of bone. The PBS was passing across the bone until the bone's color turns from red to white, demonstrating that all the marrow has been thrown out. Bone marrow total WBCs were counted.

\subsubsection{Cytological bone marrow examination.}

With a magnification of 100, bone marrow film was stained with Papanicolaou Dye. Using a low magnification capacity of the light microscope and a 100x oil immersion objective lens, the cellular density was investigated in proportion to the megakaryocytes' number. The maturation indices are determined (the ratio of the proliferative cell series and the maturative ones). Myelocytes, promyelocytes, and myeloblasts were myeloid proliferative cells, while segmented and non-segmented granulocytes, as well as metamyelocytes, were myeloid maturative cells. Rubricytes, prorubricytes, and rubriblasts constituted the erythroid proliferative series, and the metarubricytes were their maturative cells [23].

\section{Results and Discussion}

\subsection{Results.}

\subsubsection{Bone marrow examination finding.}

The findings of the bone marrow total WBC count in mice of different groups are shown in Fig 1. The number of total WBCs in the bone marrow of CP mice was reduced to less than half that of control mice. The difference in averages between the two groups is statistically significant $(\mathrm{p}<0.05)$. Sp administration to CP-treated mice increased bone marrow total WBCs markedly. The effect was more pronounced if $\mathrm{Sp}$ was given before $\mathrm{CP}$, when the average total WBCs nearly reached the control count.

The cellular bone marrow assessment and differential cell count percentage in the experimental mice were shown in Figures 2 and 3 and Tables 1 and 2. The group that received cyclophosphamide developed extreme hypocellularity. The myeloblast proportion and myeloid maturative index were markedly $(\mathrm{p}<0.05)$ lower than all other experimental groups. Furthermore, the proportion of promyelocytes, myelocytes, rubriblasts, and prorubricytes was markedly ( $\mathrm{p}<0.05$ ) lower in the experimental group than in the control group. The proportion of prorubricytes in the S. Platensis-treated group was substantially $(p<0.05)$ lower than the 
control group. When compared to the control group, all other parameters changed insignificantly $(\mathrm{p}<0.05)$. Sp extra was given before CP therapy to induce myeloid hyperplasia and hemorrhage reduction. After the mice were treated with $\mathrm{CP}$, spirulina caused marked proliferation and hypercellularity of immature myeloid components, reducing bone marrow suppression and hemorrhage. The relative increase in the proportion of myeloid to erythroid precursors after Spirulina administration is notable.

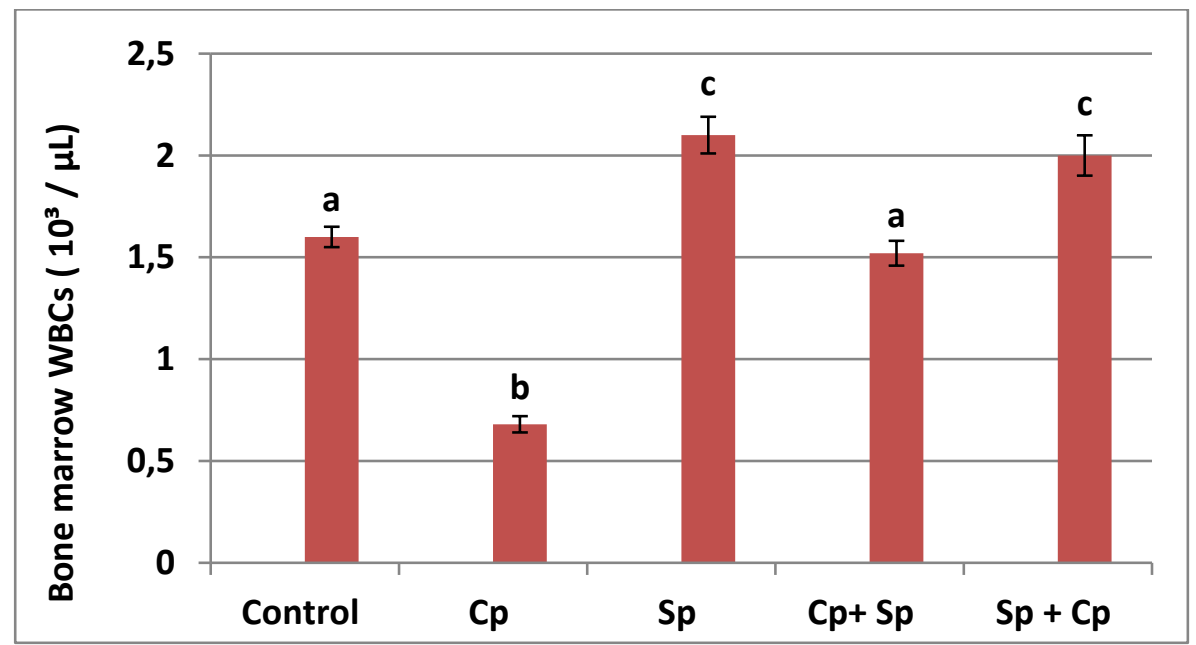

Figure 1. Total WBCs $\left(10^{3} / \mu \mathrm{L}\right)$ count in the bone marrow of mice of various groups. Data are presented as means \pm SD $(n=10)$. Different letters for the same index among the groups represent significant differences at $p$ $<0.05$.

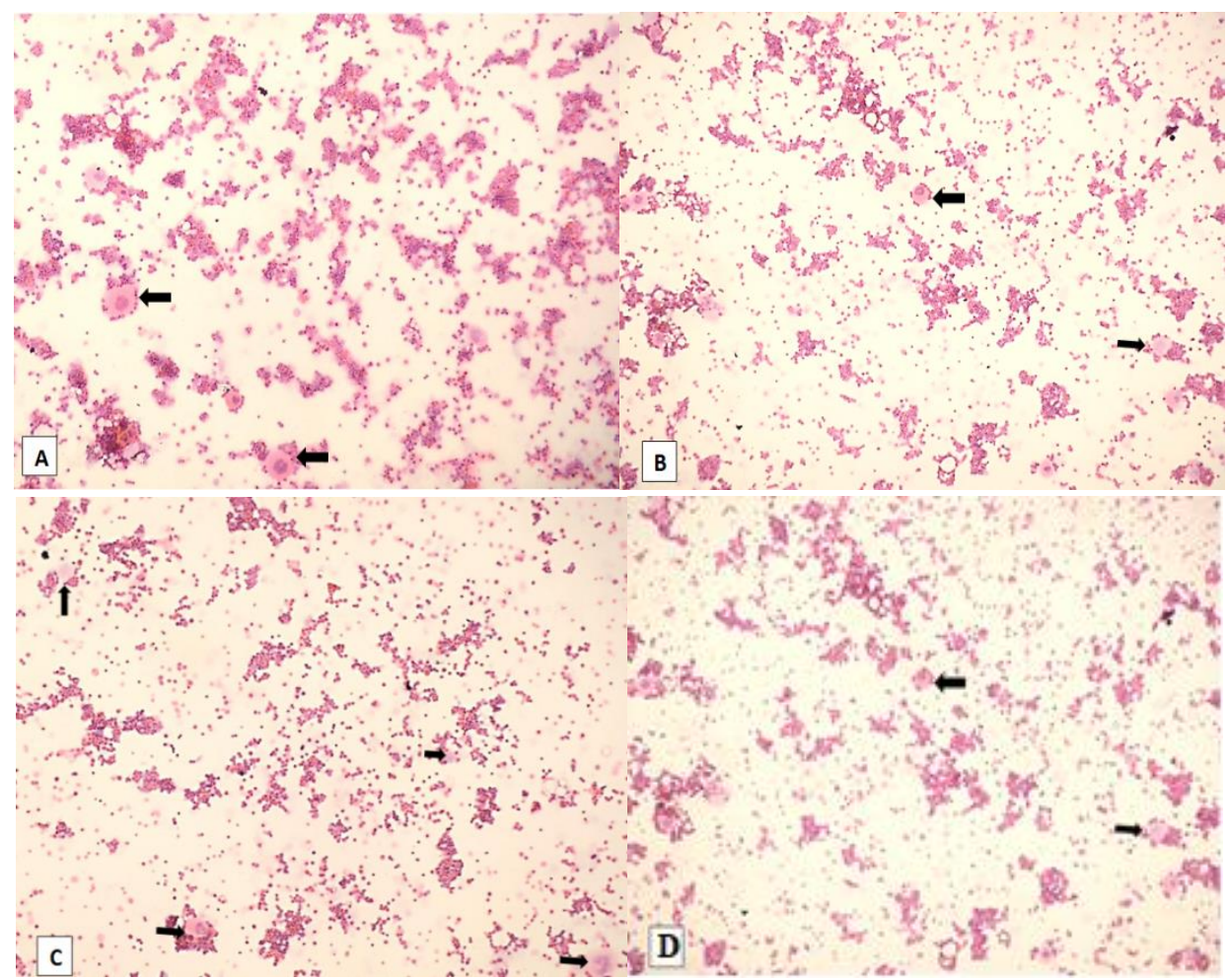

Figure 2. Bone marrow smear of experimental mice showed normal cellularity and numerous megakaryocytes (black arrows) (Papanicolaou Stain, $\times 100)$, A and B: Control group; C: Sp (1000 mg/kg) groups, D: Sp + CP group. 


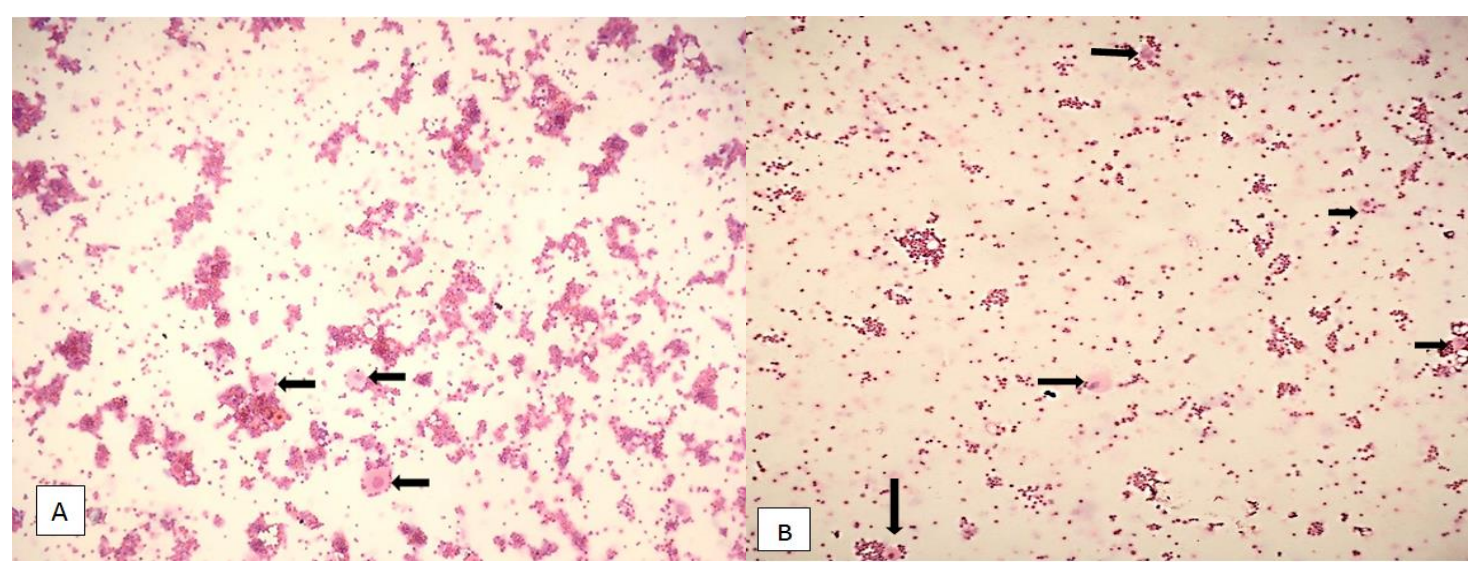

Figure 3. A: Bone marrow smear of experimental mice treated with Spirulina Platensis Extracts $(\mathrm{Cp}+\mathrm{Sp})$ showed hyperplasia. B: Bone marrow smear of $\mathrm{Cp}$ treated mice showed severe hypocellularity, many megakaryocytes (black arrows), and induced myelosuppressive effects (Papanicolaou Stain, $\times 100$ ).

Table 1. Cellular evaluation (mean \pm SE) of the bone marrow of experimental mice treated with S. Platensis.

\begin{tabular}{|c|c|c|c|c|c|c|}
\hline & $\begin{array}{l}\text { Cellular } \\
\text { density }\end{array}$ & $\begin{array}{l}\text { Myeloid } \\
\text { granulocytic series (\%) }\end{array}$ & $\begin{array}{l}\text { Myeloid } \\
\text { maturative index }\end{array}$ & $\begin{array}{l}\text { Erythroid } \\
\text { series }\end{array}$ & $\begin{array}{l}\text { Erythroid } \\
\text { maturative index }\end{array}$ & $\begin{array}{l}\text { Myeloid } \\
\text { Erythroid ratio }\end{array}$ \\
\hline Control & +++ & $53.10 \pm 2.36 \mathrm{a}$ & $0.66 \pm 0.04 \mathrm{a}$ & $45.36 \pm 2.02 \mathrm{a}$ & $1.36 \pm 0.15 \mathrm{a}$ & $1.18 \pm 0.11 \mathrm{a}$ \\
\hline Cp & + & $57.30 \pm 3.02 \mathrm{a}$ & $0.29 \pm(29 \pm 16.01 \mathrm{~b}$ & $40.23 \pm 2.70 \mathrm{a} 40.23$ & \pm 02850 进 $0.07 \mathrm{a}$ & 1.058 年世.0697a \\
\hline Sp & ++++ & $53.9 \pm 0.02 \mathrm{a}$ & $0.55 \pm 0.03 \mathrm{a}$ & $41.37 \pm 1.06 \mathrm{a}$ & $1.37 \pm 0.30 \mathrm{a}$ & $1.30 \pm 0.03 \mathrm{a}$ \\
\hline $\mathrm{Cp}+\mathrm{Sp}$ & ++ & $49.6 \pm 8.21 \mathrm{a}$ & $0.56 \pm 0.08 \mathrm{a}$ & $46.79 \pm 9.55 \mathrm{a}$ & $0.96 \pm 0.20 \mathrm{a}$ & $1.28 \pm 0.54 a$ \\
\hline $\mathrm{Sp}+\mathrm{Cp}$ & ++ & $52.40 \pm 4.21 \mathrm{a}$ & $0.61 \pm 0.07 \mathrm{a}$ & $45.79 \pm 8.55 a$ & $1.23 \pm 0.18 \mathrm{a}$ & $1.21 \pm 0.14 \mathrm{a}$ \\
\hline
\end{tabular}

+; sever hypocellular, ++; hypocellular, +++; normocellular, ++++; hypercellular

$\mathrm{a}, \mathrm{b}=$ Means with the same letter in the same raw are not significantly different at $\mathrm{p}<0.05$

Table 2. Differential cell count (\%) (Mean \pm SE) of bone marrow of experimental mice treated with $S$. Platensis.

\begin{tabular}{l|c|c|c|c|c}
$\begin{array}{l}\text { Groups } \\
\text { Parameter }\end{array}$ & Control & $\mathbf{C p}$ & $\mathbf{S p}$ & $\mathbf{C p + S p}$ & $\mathbf{S p + C p}$ \\
\hline myeloblast & $1.45 \pm 0.09^{\mathrm{a}}$ & $0.62 \pm 0.07^{\mathrm{b}}$ & $2.39 \pm 0.24^{\mathrm{c}}$ & $1.84 \pm 0.18^{\mathrm{ac}}$ & $1.73 \pm 0.41^{\mathrm{ac}}$ \\
\hline promyelocyte & $5.82 \pm 0.38^{\mathrm{ac}}$ & $3.16 \pm 0.16^{\mathrm{b}}$ & $4.89 \pm 0.25^{\mathrm{ab}}$ & $5.89 \pm 1.46^{\mathrm{ac}}$ & $4.77 \pm 0.38^{\mathrm{bc}}$ \\
\hline myelocyte & $13.81 \pm 1.18^{\mathrm{a}}$ & $8.94 \pm 0.55^{\mathrm{b}}$ & $11.82 \pm 0.80^{\mathrm{ab}}$ & $11.79 \pm 1.27^{\mathrm{ab}}$ & $10.64 \pm 1.76^{\mathrm{ab}}$ \\
\hline metamyelocyte & $15.12 \pm 2.54^{\mathrm{a}}$ & $20.80 \pm 1.83^{\mathrm{a}}$ & $12.51 \pm 1.45^{\mathrm{a}}$ & $19.10 \pm 3.94^{\mathrm{a}}$ & $17.66 \pm 6.42^{\mathrm{a}}$ \\
\hline $\begin{array}{l}\text { Non-segmented } \\
\text { granulocytes }\end{array}$ & $8.62 \pm 0.36^{\mathrm{ab}}$ & $12.65 \pm 0.65^{\mathrm{a}}$ & $9.43 \pm 4.0^{\mathrm{ab}}$ & $8.88 \pm 0.91^{\mathrm{ab}}$ & $6.09 \pm 1.46^{\mathrm{b}}$ \\
\hline $\begin{array}{l}\text { Segmented } \\
\text { granulocytes }\end{array}$ & $8.28 \pm 0.92^{\mathrm{a}}$ & $11.13 \pm 1.09^{\mathrm{a}}$ & $12.76 \pm 4.83^{\mathrm{a}}$ & $9.78 \pm 3.30^{\mathrm{a}}$ & $8.71 \pm 0.50^{\mathrm{a}}$ \\
\hline Rubriblasts & $2.69 \pm 0.37^{\mathrm{a}}$ & $1.24 \pm 0.67^{\mathrm{b}}$ & $1.87 \pm 0.36^{\mathrm{ab}}$ & $1.61 \pm 0.16^{\mathrm{ab}}$ & $2.29 \pm 0.15^{\mathrm{ab}}$ \\
\hline prorubricytes & $8.84 \pm 0.58^{\mathrm{a}}$ & $3.80 \pm 0.77^{\mathrm{b}}$ & $8.41 \pm 2.13^{\mathrm{acd}}$ & $5.29 \pm 1.02^{\mathrm{bd}}$ & $6.50 \pm 0.30^{\mathrm{abc}}$ \\
\hline rubricytes & $14.37 \pm 1.15^{\mathrm{ab}}$ & $13.38 \pm 0.99^{\mathrm{ab}}$ & $15.53 \pm 1.34^{\mathrm{ab}}$ & $18.63 \pm 1.82^{\mathrm{b}}$ & $12.92 \pm 3.10^{\mathrm{a}}$ \\
\hline metarubricytes & $19.46 \pm 2.01^{\mathrm{a}}$ & $21.82 \pm 1.98^{\mathrm{a}}$ & $15.56 \pm 0.19^{\mathrm{a}}$ & $19.22 \pm 3.29^{\mathrm{a}}$ & $25.08 \pm 6.55^{\mathrm{a}}$ \\
\hline Lymphocytes $\%)$ & $1.54 \pm 0.95^{\mathrm{a}}$ & $2.47 \pm 1.33^{\mathrm{a}}$ & $4.74 \pm 1.05^{\mathrm{a}}$ & $1.60 \pm 0.89^{\mathrm{a}}$ & $3.61 \pm 1.84^{\mathrm{a}}$
\end{tabular}

$\mathrm{a}, \mathrm{b}, \mathrm{c}, \mathrm{d}=$ Means with the same letter in the same raw are not significantly different at $\mathrm{p}<0.05$.

3.1.2. Effect of spirulina and cyclophosphamide on erythropoietin (Epo) concentration.

Figure 4 shows the effects of CP, Sp, or both on serum Epo levels in mice of multiple groups. Epo levels were severely reduced as a result of CP. There is a statistically significant distinction between the two values $(\mathrm{p}<0.05)$. Sp ingestion markedly improves the reduction in Epo levels caused by $\mathrm{CP}$, which is significantly greater than that of mice treated with $\mathrm{CP}$ alone. When Sp was given before cyclophosphamide, the improvement in serum Epo was even greater.

\subsubsection{Effect of spirulina and cyclophosphamide on blood count.}

The findings show that in cyclophosphamide (CP)-treated mice, the mean values of red blood cells (RBCs), hemoglobin concentration $(\mathrm{g} / \mathrm{dL})$, platelets count, and white blood cells 
count (WBCs) are all significantly lower $(\mathrm{P}<0.05)$ than in control mice. Spirulina was given orally to mice who had previously been injected with $\mathrm{CP}$, and it significantly enhanced platelet and WBC counts and $\mathrm{Hb}$ concentration (Table 3 ).

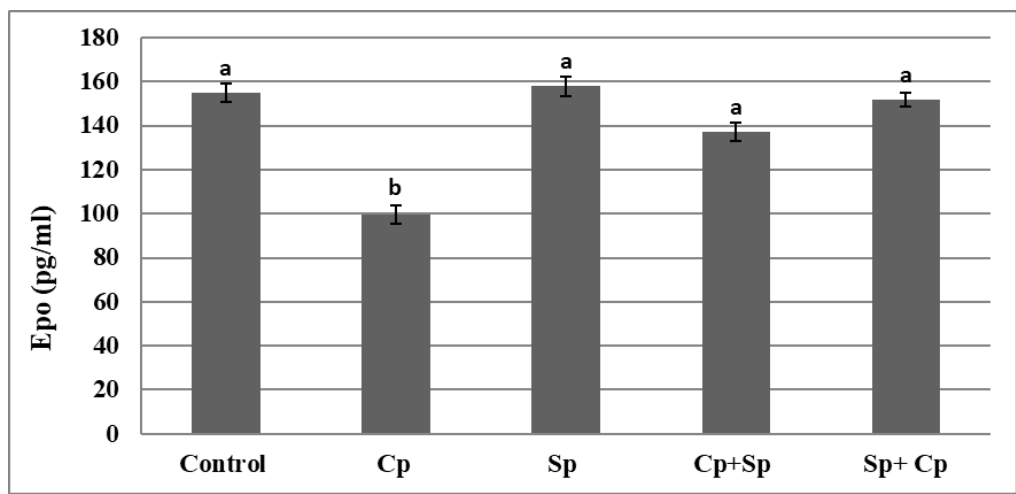

Figure 4. Erythropoietin (Epo) levels in serum of mice of different groups. Data are presented as means \pm SD (n $=10$ ). Different letters for the same index among the groups represent significant differences at $\mathrm{p}<0.05$.

Table 3. Red blood cells (RBCs), hemoglobin (Hb), platelets, and total white blood cells (WBCs) count and concentration in the blood of mice of different groups.

\begin{tabular}{l|c|c|c|c} 
Group & RBCS $(\mathbf{1 0 6} / \boldsymbol{\mu L})$ & $\begin{array}{c}\text { Hemoglobin } \\
(\mathbf{H b}) \mathbf{( g / d L )}\end{array}$ & $\begin{array}{c}\text { Platelets } \\
(\mathbf{1 0 3} / \boldsymbol{\mu L})\end{array}$ & WBCS $(\mathbf{1 0 3} / \boldsymbol{\mu L})$ \\
\hline Control & $9.90 \pm 0.21$ & $14.91 \pm 0.32$ & $1012 \pm 56$ & $8.90 \pm 0.60$ \\
\hline $\mathrm{Cp}$ & $8.10 \pm 0.46 \mathrm{a}$ & $9.30 \pm 0.31 \mathrm{a}$ & $493 \pm 52.3 \mathrm{a}$ & $4.30 \pm 0.53 \mathrm{a}$ \\
\hline $\mathrm{Sp}$ & $11.26 \pm 0.70 \mathrm{~b}$ & $16.40 \pm 0.55 \mathrm{~b}$ & $1043 \pm 57 \mathrm{~b}$ & $9.11 \pm 0.410 \mathrm{~b}$ \\
\hline $\mathrm{Cp}+\mathrm{Sp}$ & $9.71 \pm 0.22 \mathrm{~b}$ & $13.80 \pm 0.31 \mathrm{~b}$ & $804 \pm 41 \mathrm{~b}$ & $7.80 \pm 0.40 \mathrm{~b}$ \\
\hline $\mathrm{Sp}+\mathrm{Cp}$ & $9.92 \pm 0.42 \mathrm{~b}$ & $\begin{array}{c}14.90 \pm 0.50 \mathrm{~b} \\
\mathrm{a}=\text { Highly significant P-value }(\leq 0.05)\end{array}$ & $\begin{array}{c}887 \pm 43 \mathrm{~b} \\
\text { b compared to healthy control group }\end{array}$ \\
$\mathrm{b}=$ highly significant comparing to cyclophosphamide group
\end{tabular}

\subsubsection{Changes in the body weight of mice during $\mathrm{CP}$ treatment.}

The findings showed that $\mathrm{CP}$ treatment caused a continued decrease in body weight in mice compared to the control group, but that when spirulina was given to mice, the body weight of mice quickly recovered (Fig. 5, p<0.01).

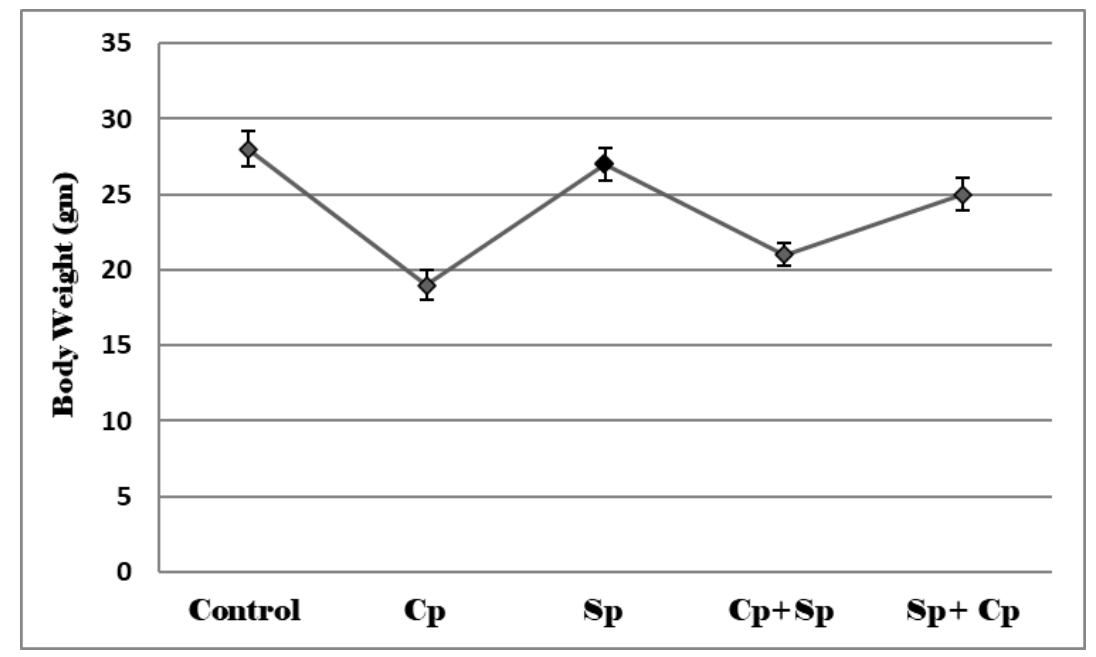

Figure 5. Changes in body-weight in $\mathrm{CP}$-induced mice.

\subsection{Discussion.}

Cyclophosphamide $(\mathrm{CP})$ is a member of the nitrogen mustard derivatives class of alkylating agents. It is a chemotherapy and immunosuppressive agent commonly used to treat 
various neoplastic and autoimmune disorders [24]. CP is also commonly used to treat a variety of malignant diseases [25], often in combination with other agents. Patients receiving CP for the treatment of solid tumors, lymphomas, and leukemias and conditioning before stem cell or bone marrow transplantation are well aware of the drug's side effects [26].

Spirulina platensis $(\mathrm{Sp})$ is a commonly used herbal medicine to treat a variety of ailments. Anti-inflammatory, anticancer, anti-diabetic, anti-microbial, anti-histaminic, antiinfertility and hypotensive effects have been indicated for Sp pharmacological properties [6]. Clinical trials have shown that Sp can be used as a complementary treatment for various diseases while also improving immune function [27]. Sp is also used to produce healthy foods, feed, and biochemical products [28].

The improvement in the survival of mouse bone marrow following toxicity caused by $\mathrm{CP}$ is reported in this study as a possible prophylactic and therapeutic effect of $\mathrm{Sp}$. The mean values of red blood cells, hemoglobin, white blood cells, and platelets were markedly lower in mice getting $\mathrm{CP}$ in this study. Also, when healthy mice receiving Sp were compared to a healthy control group, no significant differences in all hematological parameters were discovered. These results corroborated those of [29], who found that CP caused leucopenia in mice. The anemia seen in CP-treated mice may be due to chronic illness, but it could also be due to autoimmune hemolytic anemia, iron deficiency anemia, chronic kidney failure anemia, or CP myelotoxicity. In CP-treated mice, thrombocytopenia occurs as part of a larger hematological disturbance [30]. These hematological disturbances were alleviated in Sp-treated mice because blood $\mathrm{Hb}$, RBCs count, and platelet count were all improved in contrast to CP-treated mice. These results are consistent with those who found that a $30 \mathrm{mg} / \mathrm{kg}$ body-weight oral supplement of SP reduced neutrophils while increasing white blood cell count, lymphocytes, and monocyte percentages. As a result, high-dose SP supplementation is the best defense against the negative effects of diabetes on hematological parameters [31].

It was also discovered that if $\mathrm{Sp}$ was given before the CP community, hematological disruptions were decreased, suggesting that $\mathrm{Sp}$ could play an important role in the erythropoiesis process. This is reinforced by the fact that $\mathrm{Sp}$ was able to restore the lower Epo concentration caused by CP substantially. Epo is a well-known hormone that plays a role in the regulation of erythropoiesis [32]. Because of the effect of $\mathrm{CP}$ on overall WBCs, the effect of $\mathrm{CP}$ on hematological parameters can be appreciated. It was discovered that $\mathrm{CP}$ caused toxicity to the bone marrow, as shown by a decrease in total WBC count and, as previously reported, a decrease in Epo levels in the blood. Any interruption in the erythropoiesis phase can affect cell structure and, as a result, hematological parameters. These findings indicating hematological disturbances suggest that $\mathrm{CP}$ affects the bone marrow and the kidney, as EPO is primarily produced in the kidney and secreted into the bloodstream. This, in essence, promotes the development of RBCs by attacking bone marrow erythroid progenitor cells [33].

Our findings revealed that $\mathrm{Sp}$ could effectively correct the lowered serum Epo concentration caused by $\mathrm{CP}$, with the effect becoming more pronounced when $\mathrm{Sp}$ was given before $\mathrm{CP}$. In view of the effect of $\mathrm{CP}$ on overall WBCs, the effect of $\mathrm{CP}$ on hematological parameters can be appreciated. It was discovered that $\mathrm{CP}$ caused bone marrow toxicity, as demonstrated by a decline in overall WBC count and, as previously stated, a drop in Epo levels in the blood. Any interruption in the erythropoiesis phase can affect cell structure and, as a result, hematological parameters. The decrease in serum Epo concentrations in CP-injected mice appears to be mostly due to gene expression changes. However, the kidney's significance 
in this respect cannot be underestimated. Sp also appears to reverse these gene expression changes, as serum Epo levels in CP-injected mice pretreated with Sp exceeded the control limit.

Cyclophosphamide causes anemia primarily because of its myelosuppressive effect, but it also causes a deficiency of erythropoietin due to renal tubular disruption, which leads to anemia [34], anemia was discovered in CP-treated mice and may be attributable to chronic disease; however, other causes for anemia include autoimmune hemolytic anemia, iron deficiency anemia, anemia induced by chronic renal dysfunction, and CP myelotoxicity. Thrombocytopenia arises in CP-treated mice and is a symptom of a greater hematological disease. Many of these hematological disturbances were reduced in Spirulina-treated mice because blood hematological parameter counts were improved compared to Cisplatin-treated mice.

We also discovered that if spirulina was given before $\mathrm{Cp}$, the disturbance in hematological parameters was reduced and that large doses $(1000 \mathrm{mg} / \mathrm{kg} \mathrm{BW})$ had a greater effect on $\mathrm{Sp}$, indicating that spirulina could have a positive role in erythropoiesis. This is confirmed by the observation that spirulina greatly increased the decrease of bone marrow count cells caused by Cisplatin (Table 1).

The mean value of differential bone marrow cell counts, cellular density, myeloid/erythroid (M/E) ratio, and maturation index for myeloid and erythroid series are seen in the graph (table 2).

The mice given cisplatin have extreme hypocellularity, a lower number of myeloid proliferative cells like myeloblasts, promyelocytes, and myeocytes erythroid proliferative cells like rubriblastes, prorubricytes, and metarubricytes.

Furthermore, the number of myeloid maturative cells such as metamyelocytes and segmented granulocyts increased dramatically $(\mathrm{p}<0.05)$. There were no major improvements in the $\mathrm{M} / \mathrm{E}$ ratio or the erythroid maturation table. Both the megakaryocyte and myeloid maturation indices were slightly lower $(p<0.05)$ in Spirulina-treated mice than in control mice. (figure $3 \mathrm{~A}, \mathrm{~B}$ ). In CP-treated mice, the number of segmented granulocytes and metarubricytes was slightly higher $(\mathrm{p}<0.05)$ than in Sp-treated mice. There were also minor improvements in the $\mathrm{M} / \mathrm{E}$ ratio and erythroid maturation index and major increases in the myeloid maturation index and megakaryocyte proportion $(\mathrm{p}<0.0001)$. Megakaryocyte percentage was considerably increased $(\mathrm{p}<0.05)$ in $\mathrm{Sp}$ treated group than the control group (figure 4).

Some natural antioxidants have been shown to protect the structural integrity of immune cells by their antioxidant action, which clears the cell membrane of free radical oxidants [29].

\section{Conclusions}

As a result of its antioxidant effects, SP can enhance hematological parameters and bone marrow cells in mice. In light of the findings, it appears that oral intake of Spirulina platensis, when used as a chemotherapeutic agent in laboratory animals, may alleviate CP side effects on bone marrow. The power of alleviating these side effects is more beneficial when given before $\mathrm{CP}$.

\section{Funding}

This research received no external funding. 


\section{Acknowledgments}

This research has no acknowledgment.

\section{Conflicts of Interest}

The authors declare no conflict of interest.

\section{References}

1. Mills, K.A.; Chess-Williams, R.; McDermott, C. Novel insights into the mechanism of cyclophosphamideinduced bladder toxicity: chloroacetaldehyde's contribution to urothelial dysfunction in vitro. Archives of Toxicology 2019, 93, 3291-3303, https://doi.org/10.1007/s00204-019-02589-1.

2. Ayhanci, A.; Tanriverdi, D.T.; Sahinturk, V.; Cengiz, M.; Appak-Baskoy, S.; Sahin, I.K. Protective Effects of Boron on Cyclophosphamide-Induced Bladder Damage and Oxidative Stress in Rats. Biological Trace Element Research 2020, 197, 184-191, https://doi.org/10.1007/s12011-019-01969-z.

3. Morgan, C.; Tillett, T.; Braybrooke, J.; Ajithkumar, T. Management of uncommon chemotherapy-induced emergencies. The Lancet Oncology 2011, 12, 806-814, https://doi.org/10.1016/S1470-2045(10)70208-4.

4. Glen, C.D.; Dubrova, Y.E. Exposure to anticancer drugs can result in transgenerational genomic instability in mice. Proceedings of the National Academy of Sciences 2012, 109, 2984-2988, https://doi.org/10.1073/pnas.1119396109.

5. Kour, J.; Ali, M.N.; Ganaie, H.A.; Tabassum, N. Amelioration of the cyclophosphamide induced genotoxic damage in mice by the ethanolic extract of Equisetum arvense. Toxicology Reports 2017, 4, 226-233, https://doi.org/10.1016/j.toxrep.2017.05.001.

6. Wu, Q.; Liu, L.; Miron, A.; Klímová, B.; Wan, D.; Kuča, K. The antioxidant, immunomodulatory, and antiinflammatory activities of spirulina: an overview. Archives of Toxicology 2016, 90, 1817-1840, https://doi.org/10.1007/s00204-016-1744-5.

7. Omole, J.G.; Ayoka, O.A.; Alabi, Q.K.; Adefisayo, M.A.; Asafa, M.A.; Olubunmi, B.O.; Fadeyi, B.A. Protective Effect of Kolaviron on Cyclophosphamide-Induced Cardiac Toxicity in Rats. Journal of Evidence-Based Integrative Medicine 2018, 23, https://doi.org/10.1177/2156587218757649.

8. Ayza, M.A.; Zewdie, K.A.; Tesfaye, B.A.; Wondafrash, D.Z.; Berhe, A.H. The Role of Antioxidants in Ameliorating Cyclophosphamide-Induced Cardiotoxicity. Oxidative Medicine and Cellular Longevity 2020, 2020, https://doi.org/10.1155/2020/4965171.

9. Hahn, D.; Shin, S.H.; Bae, J.-S. Natural Antioxidant and Anti-Inflammatory Compounds in Foodstuff or Medicinal Herbs Inducing Heme Oxygenase-1 Expression. Antioxidants 2020, 9, http://doi.org/10.3390/antiox9121191.

10. El-Sayed, W.M.; Hussin, W.A. Antimutagenic and antioxidant activity of novel 4-substituted phenyl-2, 2'bichalcophenes and aza-analogs. Drug design, development and therapy 2013, 7, https://doi.org/10.2147/DDDT.S40129.

11. Huang, M.; Lu, J.-J.; Ding, J. Natural Products in Cancer Therapy: Past, Present and Future. Natural Products and Bioprospecting 2021, 11, 5-13, http://doi.org/10.1007/s13659-020-00293-7.

12. Alrasheid, A.A.; Babiker, M.Y.; Awad, T.A. Evaluation of certain medicinal plants compounds as new potential inhibitors of novel corona virus ( COVID - 19) using molecular docking analysis. In Silico Pharmacol 2021, 9, http://doi.org/10.1007/s40203-020-00073-8.

13. Atanasov, A.G.; Zotchev, S.B.; Dirsch, V.M.; Orhan, I.E.; Banach, M.; Rollinger, J.M.; Barreca, D.; Weckwerth, W.; Bauer, R.; Bayer, E.A.; Majeed, M.; Bishayee, A.; Bochkov, V.; Bonn, G.K.; Braidy, N.; Bucar, F.; Cifuentes, A.; D’Onofrio, G.; Bodkin, M.; Diederich, M.; Dinkova-Kostova, A.T.; Efferth, T.; El Bairi, K.; Arkells, N.; Fan, T.-P.; Fiebich, B.L.; Freissmuth, M.; Georgiev, M.I.; Gibbons, S.; Godfrey, K.M.; Gruber, C.W.; Heer, J.; Huber, L.A.; Ibanez, E.; Kijjoa, A.; Kiss, A.K.; Lu, A.; Macias, F.A.; Miller, M.J.S.; Mocan, A.; Müller, R.; Nicoletti, F.; Perry, G.; Pittalà, V.; Rastrelli, L.; Ristow, M.; Russo, G.L.; Silva, A.S.; Schuster, D.; Sheridan, H.; Skalicka-Woźniak, K.; Skaltsounis, L.; Sobarzo-Sánchez, E.; Bredt, D.S.; Stuppner, H.; Sureda, A.; Tzvetkov, N.T.; Vacca, R.A.; Aggarwal, B.B.; Battino, M.; Giampieri, F.; Wink, M.; Wolfender, J.-L.; Xiao, J.; Yeung, A.W.K.; Lizard, G.; Popp, M.A.; Heinrich, M.; Berindan-Neagoe, I.; Stadler, M.; Daglia, M.; Verpoorte, R.; Supuran, C.T.; the International Natural Product Sciences, T. Natural products in drug discovery: advances and opportunities. Nature Reviews Drug Discovery 2021, 20, 200-216, http://doi.org/10.1038/s41573-020-00114-z.

14. Nege, A.S.; Masithah, E.D.; Khotib, J. Trends in the uses of Spirulina Microalga: A Mini-Review. Jurnal llmiah perikanan dan kelautan 2020, 12, 149-166, http://doi.org/10.20473/jipk.v12i1.17506.

15. Jin, S.-E.; Lee, S.J.; Kim, Y.; Park, C.-Y. Spirulina powder as a feed supplement to enhance abalone growth. Aquaculture Reports 2020, 17, https://doi.org/10.1016/j.aqrep.2020.100318. 
16. Hu, J.; Li, Y.; Pakpour, S.; Wang, S.; Pan, Z.; Liu, J.; Wei, Q.; She, J.; Cang, H.; Zhang, R.X. Dose Effects of Orally Administered Spirulina Suspension on Colonic Microbiota in Healthy Mice. Frontiers in Cellular and Infection Microbiology 2019, 9, https://doi.org/10.3389/fcimb.2019.00243.

17. DiNicolantonio, J.J.; Bhat, A.G.; Okeefe, J. Effects of spirulina on weight loss and blood lipids: a review. Open Heart 2020, 7, https://doi.org/10.1136/openhrt-2018-001003.

18. Aguree, S.; Reddy, M.B. Inflammatory Markers and Hepcidin are Elevated but Serum Iron is Lower in Obese Women of Reproductive Age. Nutrients 2021, 13, http://doi.org/10.3390/nu13010217.

19. Gao, F.; Guo, W.; Zeng, M.; Feng, Y.; Feng, G. Effect of microalgae as iron supplements on iron-deficiency anemia in rats. Food \& Function 2019, 10, 723-732, https://doi.org/10.1039/C8FO01834K.

20. Susantad, T.; Fuangthong, M.; Tharakaraman, K.; Tit-oon, P.; Ruchirawat, M.; Sasisekharan, R. Modified recombinant human erythropoietin with potentially reduced immunogenicity. Scientific Reports 2021, 11, https://doi.org/10.1038/s41598-020-80402-1.

21. Dias, G.F.; Grobe, N.; Rogg, S.; Jörg, D.J.; Pecoits-Filho, R.; Moreno-Amaral, A.N.; Kotanko, P. The Role of Eryptosis in the Pathogenesis of Renal Anemia: Insights From Basic Research and Mathematical Modeling. Frontiers in Cell and Developmental Biology 2020, 8, https://doi.org/10.3389/fcell.2020.598148.

22. Rey, F.; Ottolenghi, S.; Giallongo, T.; Balsari, A.; Martinelli, C.; Rey, R.; Allevi, R.; Giulio, A.M.; Zuccotti, G.V.; Mazzucchelli, S.; Foresti, R.; Samaja, M.; Carelli, S. Mitochondrial Metabolism as Target of the Neuroprotective Role of Erythropoietin in Parkinson's Disease. Antioxidants 2021, 10, http://doi.org/10.3390/antiox10010121.

23. Bolliger, A.P. Cytologic evaluation of bone marrow in rats: indications, methods, and normal morphology. Veterinary clinical pathology 2004, 33, 58-67, https://doi.org/10.15406/jabb.2019.06.00173.

24. Ayza, M.A.; Zewdie, K.A.; Tesfaye, B.A.; Wondafrash, D.Z.; Berhe, A.H. The Role of Antioxidants in Ameliorating Cyclophosphamide-Induced Cardiotoxicity. Oxidative Medicine and Cellular Longevity 2020, 2020, http://doi.org/10.1155/2020/4965171.

25. Campagne, O.; Zhong, B.; Nair, S.; Lin, T.; Huang, J.; Onar-Thomas, A.; Robinson, G.; Gajjar, A.; Stewart, C.F. Exposure-Toxicity Association of Cyclophosphamide and Its Metabolites in Infants and Young Children with Primary Brain Tumors: Implications for Dosing. Clinical Cancer Research 2020, 26, 15631573, http://doi.org/10.1158/1078-0432.CCR-19-2685.

26. Abdelaty, M.M.; Gawaly, A.; Fathy, G.M.; Kabbash, I.; Taha, A. Irradiation free conditioning regimen is associated with high relapse rate in Egyptian patients with acute lymphoblastic leukemia following allogeneic hematopoietic stem cell transplantation. Journal of the Egyptian National Cancer Institute 2020, 32, 1-8, https://doi.org/10.1186/s43046-020-00042-4.

27. Ibrahim, I.A.; Shalaby, A.A.; Abd Elaziz, R.T.; Bahr, H.I. Chlorella vulgaris or Spirulina platensis mitigate lead acetate-induced testicular oxidative stress and apoptosis with regard to androgen receptor expression in rats. Environmental Science and Pollution Research 2021, http://doi.org/10.1007/s11356-021-13411-w.

28. Mathur, M. Bioactive molecules of spirulina: A food supplement. In: Bioactive Molecules in Food. Springer, Cham 2019; pp. 1621-1642.

29. Garcia, R.S.; Araújo, É.d.S.; Dambrós, B.F.; Schneider, A.; Abib, R.T. The effect of vitamin C supplementation on neutropenia induced by cyclophosphamide in mice. Revista chilena de nutrición 2019, 46, 168-173, http://doi.org/10.4067/s0717-75182019000200168.

30. Seyidoglu, N.; Gurbanli , R.; Koseli, E.; Cengiz, F.; Aydin, C. The effects of Spirulina (Arthrospira) platensis on morphological and hematological parameters evoked by social stress in male rats. Journal of Istanbul Veterinary Sciences 2019, 3, 21-27, https://doi.org/10.30704/http-www-jivs-net.544154.

31. Guldas, M.; Ziyanok-Demirtas, S.; Sahan, Y.; Yildiz, E.; Gurbuz, O. Antioxidant and anti-diabetic properties of Spirulina platensis produced in Turkey. Food Science and Technology 2020, http://doi.org/10.1590/fst.23920.

32. Zivot, A.; Lipton, J.M.; Narla, A.; Blanc, L. Erythropoiesis: insights into pathophysiology and treatments in 2017. Molecular Medicine 2018, 24, 1-15, https://doi.org/10.1186/s10020-018-0011-z.

33. Wu, Y.; Wan, Q.; Shi, L.; Ou, J.; Li, Y.; He, F.; Wang, H.; Gao, J. Siwu Granules and Erythropoietin Synergistically Ameliorated Anemia in Adenine-Induced Chronic Renal Failure Rats. Evidence-Based Complementary and Alternative Medicine 2019, 2019, https://doi.org/10.1155/2019/5832105.

34. Asada, N. Tubular immaturity causes erythropoietin-deficiency anemia of prematurity in preterm neonates. Scientific Reports 2018, 8, 1-9, https://doi.org/10.1038/s41598-018-22791-y. 